УДК 342.9

DOI

\author{
В. А. Медяник \\ orcid.org/0000 000334564472 \\ кандидат політичних наук, \\ доцент кафедри загально-правових дисииплін \\ Дніпропетровського державного університету внутрішніх справ
}

\title{
СТАН АДМІНІСТРАТИВНО-ПРАВОВОГО РЕГУЛЮВАННЯ СУЧАСНОЇ ДОКТРИНИ СОЦІАЛЬНОЇ ПОЛІТИКИ
}

Постановка проблеми. Сучасне законодавче та нормативно-правове забезпечення соціальної політики, як і загалом державної політики України, наразі перебуває на стадії формування. Адже законодавча база окремих напрямів діяльності відсутня; прослідковується тенденція щодо дублювання одних і тих самих питань у різних законодавчих документах, разом із тим трактування ïх змісту в окремих випадках $є$ різним, а іноді й суперечливим; підзаконні акти в багатьох випадках спотворюють положення окремих законів. Крім того, на думку Г.С. Лопушняк, «значна кількість нормативно-правових актів України прийнята без урахування закономірностей розвитку суспільства і об'єктивних економічних законів, теоретичного обгрунтування, а в деяких випадках - як протилежність теоретичним висновкам або здоровому глузду» [1]. I незважаючи на той факт, що останнім часом процес розробки законодавчого та нормативно-правового забезпечення соціальної політики дещо активізувався, він потребує вдосконалення.

Аналіз останніх досліджень і публікацій. Питання щодо правового регулювання соціальної політики, її окремих напрямів висвітлено в наукових працях таких вчених, як В.П. Антонюк, I.А. Грицяк, Г.С. Лопушняк, В.М. Молоканова, Н.М. Мужикова, І.Г. Оксьом, Л.А. Семиног, О.Ю. Тюлєнева, П.І. Шевчук та інші. Проте незважаючи на вагомий внесок даних досліджень у науку права, у зв'язку із триваючими реформами, складною економічною та політичною ситуацією у країні і, відповідно, суттєвими змінами законодавства, нормативно-правове регулювання соціальної політики потребує додаткового вивчення.

Метою статті $€$ аналіз основних нормативно-правових актів, які регламентують діяльність у напрямі соціальної політики, виокремлення проблемних питань та надання рекомендацій щодо їх удосконалення.

Виклад основного матеріалу. Основним законом України є її Конституція, яка визначає найбільш загальні концептуальні підходи до формування соціальної політики, побудови соціальної держави. До основних програмних документів, які визначають стратегію державної соціальної політики на державному рівні, відносять:
Стратегію сталого розвитку «Україна - 2020», затверджену указом Президента України від 12.01.2015 p. № 5 [2]; Програму діяльності Кабінету Міністрів України, затверджену постановою від 12.06.2020 р. № 471 [3]; наказ Міністерства соціальної політики України «Про затвердження Стратегічного плану діяльності Міністерства соціальної політики України на 2020 бюджетний рік і два бюджетні періоди, що настають за плановим (2021-2022 роки)» від 07.02.2020 р. № 97 [4].

Крім того, державна соціальна політика має не тільки загальнодержавний, але і регіональний, i місцевий рівень. Засади соціальної політики на регіональному рівні передбачено в Державній стратегії регіонального розвитку на період до 2020 року [5], а місцевої соціальної політики - у відповідних Стратегіях розвитку областей України.

Коротко проаналізуємо зазначені документи. Загальні засади державної соціальної політики визначено у Стратегії сталого розвитку «Україна - 2020». Даний документ передбачає в рамках чотирьох векторів руху реалізацію 62 реформ та програм розвитку держави, пріоритетними серед яких у соціальній сфері визначено: реформа сфери трудових відносин; реформа системи соціального захисту; пенсійна реформа; реформа системи охорони здоров'я; реформа освіти; програма розвитку для дітей та юнацтва. Першочерговою серед них визначено реалізацію реформи системи охорони здоров'я. Метою державної політики в даному напрямі є кардинальне, системне реформування, спрямоване на створення системи, орієнтованої на пацієнта, здатної забезпечити медичне обслуговування для всіх громадян України на рівні розвинутих європейських держав [2].

Таким чином, вказана Стратегія лише визначає певні напрямки розвитку окремих секторів соціальної сфери без деталізації змісту відповідних реформ (крім реформи системи охорони здоров'я), яка визначена пріоритетом. Можна припустити, що інші реформи мають відбуватися повільно, без вжиття кардинальних заходів в інших галузях соціальної сфери.

Отже, Стратегія передбачає узагальнені напрями трансформацій у соціальній сфері, відповідно до яких уряд зобов'язаний розробити акти у вигляді програмно-цільових документів реформи. 
Однак наразі вже можна констатувати, що окремі програмні документи, підготовлені Кабінетом Міністрів України та профільними міністерствами на виконання положень Стратегії у соціальній сфері, не стали дієвим механізмом, за допомогою якого мали б бути реалізовані всі зазначені реформи. Недоліком Стратегії є те, що вона не вказує шляхів розвитку пріоритетних галузей соціальної сфери, тобто є декларацією намірів.

Наступним документом, який визначає державну соціальну політику, є Програма діяльності Кабінету Міністрів України, яка містить заходи розвитку соціальної сфери та повноваження центральних органів виконавчої влади з їх реалізації. У Програмі діяльності Кабінету Міністрів України зазначено, що даний документ - це реакція Уряду на ряд проблем, які постали перед нашою країною, а також порядок денний діяльності на середньо- та довгостроковий період для забезпечення економічного розвитку та, як наслідок, підвищення благополуччя населення. Пріоритетами в даному документі визначено: подолання Російської агресії; зменшення поширення пандемії; подолання економічної кризи; реалізація курсу на європейську та євроатлантичну інтеграцію [3].

У відповідь на термінові виклики у вигляді пандемії та економічної кризи у червні 2020 року Урядом було розроблено Програму стимулювання економіки, основна мета якої - подолання негативних наслідків, спричинених обмежувальними заходами щодо запобігання виникненню i поширенню коронавірусної хвороби (COVID-19). Вона включає в себе ряд коротко- та середньострокових заходів для пріоритетних галузей економіки України на 2020-2022 роки [3]. У цілому стимулювання економічного розвитку держави є найбільшим пріоритетом вказаної програми.

У Програмі діяльності Кабінету Міністрів України окремими пунктами визначено повноваження Міністерства соціальної політики з розвитку соціальної сфери в таких напрямах: соціальні стандарти та якісні послуги; гідне пенсійне забезпечення; підтримка незахищених верств населення; підтримка осіб з інвалідністю; сімейна політика, захист прав дітей.

Варто зазначити, що з метою визначення основних завдань Міністерства соціальної політики України на 2020 бюджетний рік і два бюджетні періоди, що настають за плановим (2021-2022 рр.), а також з урахуванням цілей, визначених для Мінсоцполітики, Програмою діяльності Кабінету Міністрів України, схваленою постановою Верховної Ради України від 04.10.2019 р. № 188-IX, і статтею 22 Бюджетного кодексу України Міністерство соціальної політики затвердило Стратегічний план діяльності на період 2020-2022 роки.

Місія Міністерства соціальної політики України полягає у формуванні та реалізації державної соціальної політики, спрямованої на створення умов для інтеграції осіб з інвалідністю у суспільне життя, забезпечення прав та інтересів дітей, сприяння їх вихованню у сімейному середовищі, надання соціальної підтримки особам і сім'ям, які перебувають у складних життєвих обставинах та самостійно не можуть їх подолати, забезпечення гідної старості, створення середовища рівних прав і можливостей для жінок і чоловіків [4].

Аналізуючи зміст наведених вище документів, не можемо не звернути увагу на такі факти:

- по-перше, наявні програмні документи розвиток соціальної сфери розглядають не як пріоритет, а в контексті реалізації європейської інтеграції та подолання економічної кризи;

- по-друге, вказані програмні документи передбачають пріоритети трансформацій у таких галузях соціальної сфери, як: соціальна підтримка окремих верств населення; гендерна рівність; інклюзія соціальної сфери: реформа системи охорони здоров'я та освіти. Розвиток інших галузей соціальної сфери першочергового пріоритету не має, хоча державою передбачається фрагментарна реалізація певних заходів;

- по-третє, проаналізовані вище програмні документи є неузгодженими між собою щодо напрямів розвитку тих чи інших галузей соціальної сфери. Зокрема, Стратегія сталого розвитку передбачає: реформи системи соціального захисту; пенсійну реформу; реформу системи охорони здоров'я; реформу освіти; програму розвитку для дітей та юнацтва. Відповідно, вектори цих реформ мають бути деталізовані та передбачені у Програмі діяльності Уряду та деталізовані у програмно-цільових документах профільних міністерств. Однак, як можна переконатися, окремі реформи в соціальній сфері Міністерством соціальної політики України не деталізовано.

Таким чином, можна стверджувати, що прийняття наведених вище та інших програмно-цільових документів створюють сприятливі умови для розвитку соціальної сфери, проте реалізація намірів Стратегії, Планів діяльності тощо залежить від наявності узгодженості їх заходів між собою, системної та покрокової технології розробки та реалізації цих програм.

Крім того, розгортання процесів реалізації стратегії залежить від наявності та ефективності відповідних інституцій, фінансової підтримки сталого розвитку та кваліфікованого кадрового забезпечення. У цілому в Україні готовність і спроможність до такої діяльності є недостатньою. I проблема полягає не лише у складності та новизні завдань, а й у відсутності системної методології та дієвих механізмів управління сталим розвитком та соціальною сферою [6].

Упровадження стратегічних планів економічного та соціального розвитку важливі як власне 
для окремих територіальних одиниць, так і для держави в цілому. Проте, зазначає В.М. Молоканова, якщо в кожному конкретному випадку не були чітко визначені кількісні та якісні результати реалізації програм розвитку, терміни їх виконання, відповідальні виконавці та механізми оцінювання досягнення запланованого результату - більшість позитивних стратегічних змін залишаються лише на папері. Саме відсутність застосування всіх відомих механізмів проектного менеджменту стає причиною незадоволення громадськості щодо реалізації стратегій [6].

Таким чином, крім складної економічної ситуації, недофінансування соціальної сфери, проблемні питання залишаються нерозв'язаними, i це в першу чергу зумовлено відсутністю єдиної, комплексної стратегії соціальної політики держави. Серед основних недоліків доцільно виокремити відсутність узгодженості положень між собою, перенасиченість фразами-побажаннями, декларативність положень, відсутність конкретних заходів та конкретних шляхів їх реалізації.

Основними завданнями нормативно-правового регулювання соціальної політики повинні бути максимальне збереження фізичного, інтелектуального, духовно-етичного потенціалу країни; формування ефективної системи трудової мотивації, яка відповідає вимогам сучасного ринку праці. Без цього неможливий економіко-правовий підйом, ефективна економіка, повноцінний ринок; створення інституціональних і соціально-економічних передумов для реалізації громадянами, різними суспільними прошарками і групами населення своїх потреб та інтересів, прояву своєї активності й розкриття особистості. Саме це створює передумови громадянського суспільства, особистої свободи, реальної демократії [7, с. 67]. Неефективність правового механізму регулювання призводить до того, що нові спроби регулювання соціальних процесів на певних рівнях стають недієвими.

Висновки. Отже, за результатами проведеного дослідження встановлено, що сьогодні відсутня комплексність та системність під час визначення змісту програмних документів щодо соціальної політики, не визначено їх ієрархію, недосконалою є науково-теоретична та методологічна розробка стратегії, концепції, планів дій розвитку соціальної сфери. Сучасна стратегія державної політики має Iрунтуватися на політичних, економічних, правових і організаційних заходах. Вона повинна бути втілена у програмному документі, в якому мають ці заходи міститися і закріплюватися, а також передбачати повноваження органів публічної адміністрації з її реалізації. Тобто сучасна стратегія державної політики має також визначати і механізми її впровадження, а не бути декларацією намірів. Лише в такому разі можна вести мову про ефективність її реалізації. Дана тематика і стане перспективою наших подальших наукових досліджень.

\section{Jimepamypa}

1. Лопушняк Г.С. Державна соціальна політика як передумова економічного розвитку України : монографія. Львів : ЛРІДУ НАДУ, 2011. 372 с. С. 38.

2. Стратегія сталого розвитку «Україна - 2020» : указ Президента України від 12.01.2015 р. № 5 . URL : zakon.rada.gov.ua/laws/show/5/2015\#Text.

3. Програма діяльності Кабінету Міністрів України: постанова Кабінету Міністрів України від 12.06.2020 p. № 471. URL : www.kmu.gov.ua/npas/ pro-zatverdzhennya-programi-diyalnosti-kabinetuministriv-t120620.

4. Про затвердження Стратегічного плану діяльності Міністерства соціальної політики України на 2020 бюджетний рік і два бюджетні періоди, що настають за плановим (2021-2022 рр.): наказ Міністерства соціальної політики України від 07.02.2020 р. № 97. URL : www.msp.gov.ua/documents/5641.html.

5. Про затвердження Державної стратегії регіонального розвитку на період до 2020 року : постанова Кабінету Міністрів України від 06.08.2014 р. № 385. URL: www.minregion.gov.ua/napryamki-diyalnosti/ derzhavna-rehional-na-polityka/strategichneplanuvannya-regionalnogo-rozvitku/derzhavnastrategiya-regionalnogo-rozvitku-na-period-do-2020roku.

6. Молоканова В.М. Моніторинг практичної реалізації стратегії сталого розвитку в Україні. Аспекти публічного управління. 2018. Т. 6. № 11-12. С. 85-92.

7. Ткач O. Особливості державної політики у сфері соціального розвитку України. Освіта регіону. 2013. № 2. C. 67-71. URL : http://social-science.com. ua/article/1035.

\section{Анотація}

Медяник B. A. Стан адміністративно-правового регулювання сучасної доктрини соціальної політики. - Стаття.

У статті проаналізовано основні нормативно-правові акти, які регламентують діяльність у напрямі соціальної політики. Констатовано, що сьогодні законодавче та нормативно-правове забезпечення соціальної політики перебуває на стадії формування (відсутне законодавче підгрунтя окремих напрямів діяльності; наявне дублювання одних і тих самих питань у різних законодавчих документах; підзаконні акти в багатьох випадках спотворюють положення окремих законів). Визначено, що основним законом України є її Конституція, до основних програмних документів, які визначають сучасну стратегію державної соціальної політики на державному рівні, віднесено Стратегію сталого розвитку «Україна - 2020», Програму діяльності Кабінету Міністрів України, наказ Міністерства соціальної політики України «Про затвердження Стратегічного плану діяльності Міністерства соціальної політики України на 2020 бюджетний рік і два бюджетні періоди, що настають за плановим (2021-2022 роки). Теоретично обгрунтовано, що наявні програмні документи в напрямку соціальної політики: розвиток соціальної сфери розглядають не як пріоритет, а в контексті реалізації європейської інтеграції та подолання економічної кризи; передбачають пріоритети трансформацій у таких галузях соціальної сфери, як: соціальна під- 
тримка окремих верств населення; гендерна рівність; інклюзія соціальної сфери: реформа системи охорони здоров'я та освіти. Розвиток інших галузей соціальної сфери першочергового пріоритету не має, хоча державою передбачається фрагментарна реалізація певних заходів; є неузгодженими між собою щодо напрямів розвитку тих чи інших галузей соціальної сфери. Зроблено висновок, що сьогодні відсутня комплексність та системність у визначенні змісту програмних документів щодо соціальної політики, не визначено їх ієрархію, недосконалою $є$ науково-теоретична та методологічна розробка стратегії, концепції, планів дій розвитку соціальної сфери. Сучасна стратегія державної політики має Ірунтуватися на політичних, економічних, правових i організаційних заходах. Вона повинна бути втілена у програмному документі, в якому мають ці заходи міститися і закріплюватися, а також передбачати повноваження органів публічної адміністрації з їі реалізації.

Ключові слова: соціальна політика, законодавство, реформування, стратегія розвитку, пріоритетність, удосконалення, правові механізми.

\section{Summary}

Medianyk V.A. The state of administrative and legal regulation of modern doctrine of social policy. - Article.

The article analyzes the main legal acts that regulate activities in the direction of social policy. It is stated that today the legislative and regulatory support of social policy is in the process of formation (there is no legislative basis for certain activities; there is duplication of the same issues in different legislative documents; bylaws in many cases distort the provisions of certain laws). It is deter- mined that the basic law of Ukraine is its Constitution, the main program documents that determine the modern strategy of state social policy at the state level include the Strategy of Sustainable Development "Ukraine - 2020", the Cabinet of Ministers of Ukraine, the order of the Ministry of Social Policy of Ukraine the activity plan of the Ministry of Social Policy of Ukraine for the 2020 budget year and the two budget periods following the planned one (2021-2022). It is theoretically substantiated that the available program documents in the direction of social policy: the development of the social sphere is considered not as a priority, but in the context of the implementation of European integration and overcoming the economic crisis; provide priorities for transformations in such areas of the social sphere as: social support of certain segments of the population; gender equality; social inclusion: health and education reform. The development of other branches of the social sphere is not a priority, although the state envisages the fragmentary implementation of certain measures; are inconsistent with each other on the directions of development of certain branches of the social sphere. It is concluded that today there is no complexity and systematization in determining the content of program documents on social policy, their hierarchy is uncertain, scientific-theoretical and methodological development of strategy, concept, action plans for social development is imperfect. Modern public policy strategy should be based on political, economic, legal and organizational measures. It should be embodied in the program document, in which these measures should be contained and enshrined, as well as provide for the powers of public administration bodies to implement it.

Key words: social policy, legislation, reform, development strategy, priority, improvement, legal mechanisms. 